\title{
Prophesying Women and Ruling Men: Women's Religious Authority in North American Pentecostalism
}

\author{
Lisa P. Stephenson \\ Department of Theology, Lee University, P.O. Box 3450, Cleveland TN 37320-2450, USA; \\ E-Mail: 1stephenson@leeuniversity.edu; Tel.: +1-423-303-5091; Fax: +1-423-303-5109
}

Received: 12 June 2011; in revised form: 15 August 2011 / Accepted: 19 August 2011 /

Published: 29 August 2011

\begin{abstract}
The issue of religious authority is one of the main reasons why women have been allowed to participate in Pentecostal churches, and why they have been limited. Women are granted access to ministering authority, but not governing authority. Charles Barfoot and Gerald Sheppard have noted the presence of these two types of authority to be operative within Pentecostalism and have associated them with Max Weber's typology of prophet and priest. However, in their attempt to describe the history of Pentecostal women in ministry with these categories, Barfoot and Sheppard present the paradigm as one of displacement rather than coexistence. The result is a problematic and misleading account of Pentecostal women in ministry. However, the issue is not Weber's categories, but how they employ them. The purpose of this article is to utilize the distinction between prophet and priest to differentiate between two types of ecclesial functions and their concomitant religious authority, rather than to differentiate between two periods of Pentecostalism. A brief history of Pentecostal women in ministry is presented, wherein examples are offered of how women in the Church of God, the Church of God in Christ, the Assemblies of God, and the International Church of the Foursquare Gospel operated in the prophetic realms with a ministering authority, but were largely prohibited from the priestly realms and its ruling authority. As these examples demonstrate, the history of Pentecostal women in ministry is told best when the simultaneous existence of the prophetic and priestly functions are recognized, and ministering authority and ruling authority are connected to these two functions.
\end{abstract}

Keywords: Pentecostalism; religion; women; gender; leadership; ministry; authority; power 


\section{Introduction}

"We know of no Movement where women of ability and filled with the Holy Ghost, have been much more highly honored or given much more freedom than among us" [1]. This is what an early leading Pentecostal figure, E.N. Bell, claimed in one of his editorials as he reflected on women's roles within the Pentecostal denomination the Assemblies of God. Bell is not the only one who offers such a high estimation of women's place within early Pentecostalism. His view is echoed among contemporary scholarship [2-6]. As interest in the history of women in American religion has increased, the Pentecostal tradition has gained widespread attention for the atypical ministerial roles women occupied during the beginning of the movement. While Pentecostal women operated with more religious authority compared to women in other denominations throughout the United States in the early part of the twentieth century, even during the beginning of the Pentecostal movement complete egalitarianism did not exist. The Pentecostal male leadership has repeatedly circumscribed Pentecostal women's religious authority despite the predominant belief of Spirit empowerment within this tradition.

The issue of authority is one of the main reasons why women have been allowed to participate in Pentecostal churches, and why they have been limited. Because Pentecostalism is a tradition centered on the event of Pentecost, for them the outpouring of the Spirit in the book of Acts is more than just an historical account. It is a living reality that is continuing today in order to empower the church once again as the Spirit is being poured out on men and women. Understanding authority as legitimated power, Pentecostal women gain access to a realm of religious authority because of their experience of Spirit baptism. That is, because of their experience of Spirit baptism Pentecostal women are granted an authority to minister in certain ways since the evidence of the Spirit in their lives (e.g., glossolalia or other spiritual gifts) legitimates their function in these areas. However, according to some Pentecostals, Spirit baptism does not impute to women the religious authority to hold ruling offices. Pentecostals identify the legitimation of this type of authority with one's male identity, not with Spirit baptism per se.

Scholars have noted the presence of these two types of authority (i.e., ministering authority and ruling authority) to be operative within Pentecostalism and have associated them with Max Weber's typology of "prophet" and "priest," respectively. In Weber's The Sociology of Religion, he offers the categories of prophet and priest to describe two different types of religious leaders. Weber describes a prophet as one who lays claim to authority by virtue of personal revelation and charisma, while a priest is one who lays claim to authority by virtue of his or her service in a sacred tradition. It is the personal call that distinguishes the prophet from the priest. Moreover, Weber also claims that among the religion of the disprivileged classes there is a tendency to allot equality to prophetic women during the developing phases because pneumatic manifestations of charisma are valued among the religious community during this time. However, as the community becomes more routinized and regimented a reaction takes place against these types of manifestations, and, thus, against prophetic women [7]. Charles Barfoot and Gerald Sheppard are the first two Pentecostal scholars to apply Weber's ideas to the situation of Pentecostal women and subsequent scholars follow in their footsteps [4,8-10]. In their article, "Prophetic vs. Priestly Religion: The Changing Role of Women Clergy in Classical Pentecostal Churches," Barfoot and Sheppard utilize Weber's categories of prophet and priest to describe the functions of Pentecostal ministry, as well as to serve as descriptors of two different eras of 
Pentecostalism. With respect to the first issue, Barfoot and Sheppard identify pastoral and preaching/teaching functions as prophetic because the authority for these functions resides within personal revelation and charisma. They identify certain administrative responsibilities and administration of church ordinances as priestly because the authority for these functions resides within service to the religious tradition. With respect to the second issue, Barfoot and Sheppard want to account for the current scarcity of Pentecostal women in ministry and believe that Weber's observation about women in disprivileged classes explains the situation. Therefore, they employ the categories of prophet and priest symbolically to describe the function of Pentecostal leadership. During "Prophetic Pentecostalism" (1901-1920s) prophetic women (i.e., women who operated with ministering authority because they demonstrated pneumatic manifestations of charisma) were welcomed and granted an early equality, but during "Priestly Pentecostalism" (1920s-1980s) this equality faded away as the community relationships within Pentecostalism became routinized and regimented [2].

While Weber's categories of prophet and priest are helpful in distinguishing between two types of ministerial functions and their concomitant claims to authority, Barfoot and Sheppard's utilization of them to distinguish two different eras of Pentecostalism is problematic. That is, in their attempt to describe the history of Pentecostal women in ministry with these categories, Barfoot and Sheppard present the paradigm as one of displacement rather than coexistence. "Prophetic Pentecostalism" is replaced by "Priestly Pentecostalism." Although Barfoot and Sheppard's account highlights relevant issues, ultimately it is problematic and misleading because it distorts the historical reality. There is no dramatic shift with respect to women's religious authority from early Pentecostalism to later Pentecostalism. Pentecostal women have always had access to prophetic functions, and always struggled with access to priestly functions. However, one need not discard the typology of prophet and priest altogether. The issue is not the categories, but how they employ them. The purpose of this article is to utilize the distinction between prophet and priest to differentiate between two types of ecclesial functions and their concomitant authority, rather than to differentiate between two periods of Pentecostalism. I will proceed by first laying out how Barfoot and Sheppard utilize Weber's ideas within their own work. I will then present a brief history of Pentecostal women in ministry through the lens of ministering authority and ruling authority, and demonstrate how these two realms of authority have been linked to the prophetic and priestly functions, respectively. The history of Pentecostal women in ministry is told more accurately when the simultaneous existence of the prophetic and priestly functions are recognized, and ministering authority and ruling authority are connected to these two functions.

\section{Pentecostal Women in Ministry: "Prophetic Pentecostalism" and "Priestly Pentecostalism"}

Barfoot and Sheppard cite three central factors that contributed to the egalitarian atmosphere of "Prophetic Pentecostalism." The first is that the only distinguishing characteristic between the laity and clergy was the personal call. This emphasis perpetuated "prophetic" leadership since it is the personal call that distinguishes the prophet from the priest, and Pentecostals usually communicated their calling in paradigms similar to the biblical calling narratives of the prophets. Because Pentecostals understood pastoral and preaching functions to be aspects of the prophetic, anyone laying claim to the personal call could operate in these arenas-including women. In order to illustrate this feature of "Prophetic 
Pentecostalism," Barfoot and Sheppard focus on Aimee Semple McPherson. McPherson was one of Pentecostalism's most widely-recognized female ministers, and she frequently referenced her call to ministry. She relayed the initial call in terms reminiscent of the prophet Jeremiah's call, claimed to have suffered physical problems because of her resistance to the call, and associated her recovery and subsequent career as a minister with finally accepting her call [2].

The second variable is that the demonstration of charisma - understood as the anointing of the Holy Spirit - confirmed for the larger religious community that indeed God had called one to the ministry. Charisma was the legitimation of one's authority to function in the prophetic and, because of the outpouring of the Holy Spirit on men and women, women had access to this authority. Barfoot and Sheppard offer excerpts from the Azusa Street revival as proof of the value that early Pentecostals placed on charisma. These excerpts note that the charisma of women was recognized and even appreciated. Moreover, in the Assemblies of God the presence of charisma among women was offered as a reason for ordination [2].

The third variable is that the act of women ministering was perceived by the religious community to be a sign of the impending eschaton. Pentecostals were fulfilling biblical prophecy by allowing women to operate in the prophetic functions of the church. Barfoot and Sheppard demonstrate this by highlighting McPherson and her interpretation of what "prophesying" meant. She, like many other Pentecostals, claimed that to prophesy meant to preach. Therefore, when the Acts 2 passage claims that "in the last days" the Spirit will be poured out on sons and daughters in order to prophesy, the biblical texts are offering an injunction for women to preach in order to usher in the second coming of the Lord [2].

These three factors, however, became less significant as Pentecostalism transitioned from its prophetic phase to its priestly phase. Barfoot and Sheppard maintain that the shift from "Prophetic Pentecostalism" to "Priestly Pentecostalism" occurred because of organizational changes that took place. During the 1920s community relationships began to be routinized and regimented, though evidence of this was already occurring as early as 1914. As ecclesiastical authority was centralized, the socioreligious function of preaching shifted from a prophetic to a priestly performance. The Pentecostal "priesthood" began to solidify and the male monopolization of this authority was made complete. According to Barfoot and Sheppard, it is more than ironic that McPherson left the Assemblies of God when the change began to occur [2].

Barfoot and Sheppard document the shift by examining significant alterations that took place within the Assemblies of God during four General Council meetings. Their assumption is that what was taking place in this particular Pentecostal denomination at that time is typical for what was taking place in other Pentecostal denominations during the same period. At the 1917 General Council a gradation of clergy emerges and a centralization of ecclesiastical authority begins. Rather than just recognizing ministers as ordained, after 1917 ministers first had to be proved as licentiates and then they could be ordained. Moreover, no longer was the local church the sole administering body for ordination, but the district councils were granted this privilege as well. Barfoot and Sheppard claim that the gradation in ministerial credentials made it harder for women to move out of the "licensed" category into the "ordained." At the 1923 General Council, members expressed a need for ministerial training and a resolution was adopted to set the process in motion. Soon thereafter, the Central Bible Institute emerged. Women were permitted to attend, but emphasis was placed on the need for more 
male students. Then at the 1927 General Council the centralization of ecclesiastical authority advanced further as the right to examine, license, and ordain ministers was given to the district council. According to Barfoot and Sheppard, this implied that in order for one to be a Pentecostal minister more would be required than a report of a personal call and the recognition of charisma by the local church. Finally, at the 1931 General Council the members passed a resolution that denied ordained women the right to bury the dead, administer the ordinances (i.e., sacraments) of the church, or perform the right of marriage - rights that women were entitled to earlier. While this was reversed in 1935, Barfoot and Sheppard conclude that with the rise of "Priestly Pentecostalism" women would never have the same freedoms they had earlier on in the movement [2].

As noted above, though Barfoot and Sheppard's account raises significant issues when considering the role of Pentecostal women, their interpretive lens of "Prophetic Pentecostalism" and "Priestly Pentecostalism" is ultimately problematic. Their presentation of "Prophetic Pentecostalism" is too optimistic with respect to the "equality" that women had during the early formation of Pentecostalism. Their focus on one female minister (Aimee Semple McPherson) and one Pentecostal denomination (Assemblies of God) to substantiate their claims of two periods of Pentecostalism is too limited of an approach and does not take into consideration historical differences among other Pentecostal denominations. In order to relay more accurately the history of Pentecostal women in ministry I will focus below on the two types of religious authority operating within Pentecostalism - which can be associated with the prophetic and the priestly_and demonstrate that both were present from the very inception of the movement.

\section{Rescripting the Narrative: Ministering Authority and Ruling Authority}

\subsection{The Azusa Street Revival}

The beginning of classical Pentecostalism is associated with the Azusa Street revival in Los Angeles from 1906-1909. This revival was one of the first formative events and the primary catalyst that launched Pentecostalism into a worldwide movement as the people who visited Azusa returned to their homes spreading the Pentecostal message across the world. The events of the revival and the theology emerging from it enabled Pentecostal women a certain amount of religious authority. This was the case primarily because Pentecostals believed that it was the Spirit of God ministering through the women and thus they should not hinder the Spirit. Consequently, Pentecostal women who demonstrated any type of ministering authority by way of preaching, teaching, or evangelizing were not only tolerated, but expected. These prophetic functions were legitimated because of the power of the Spirit, which - as Barfoot and Sheppard note-was confirmed through the means of calling and charisma. However, when it came to functioning in priestly roles that were understood to possess ruling authority (e.g., elders, church officials, denominational leaders), women were excluded on the basis of their sex. Legitimation for this type of authority required more than just an experience of Spirit baptism; one must also be male.

Contrary to Barfoot and Sheppard's claims, Pentecostals were already distinguishing between the prophetic functions of ministering authority and the priestly functions of ruling authority from the very beginning of the movement. Based on an eyewitness account of the Azusa Street meetings by Frank 
Bartleman, it is apparent that there was a general level of openness toward women operating with ministering authority. When describing the meetings, Bartleman maintains that there was no type of formal program or schedule because there was a communal expectation that "the Lord was liable to burst through anyone....It might be a child, a woman or a man. It might be from the back seat or from the front row. It made no difference" [11]. People were honored for their spiritual gifts, rather than their natural talents or status. Yet, while on the one hand Bartleman can affirm the potential for God to "burst" through any person at the Azusa Street meetings, including women, on the other hand he does not support the complete equality of women in the ministry. In a different publication Bartleman strongly denounces women being equal to men or ruling over them in church government. He goes so far as to state that, "A female ministry is naturally a weak ministry....God is not changing His order, raising woman to equality with man in the ministry. The Apostles were men. The early church is our example. God made Adam first. Then the woman for his helper" [12]. While Bartleman does acknowledge that women have a certain place in the church, according to him it certainly is not one that involves possessing any type of ruling authority.

These ideas are not exclusive to Bartleman. The same type of description of women's limited roles in the church are echoed in a piece that appeared in 1908 in the Apostolic Faith, which was the monthly newsletter published by the Azusa Street Mission for the first two years of the revival. In an anonymous article entitled "Who May Prophesy?" it said,

Before Pentecost, the woman could only go into the "court of women" and not into the inner court. The anointing oil was never poured on a womans [sic] head but only on the heads of kings, prophets and priests. But when our Lord poured out Pentecost, He brought all those faithful women with the other disciples into the upper room, and God baptized them all in the same room and made no difference. All the women received the anointed oil of the Holy Ghost and were able to preach the same as men.

The woman is the weaker vessel and represents the tenderness of Christ, while the man represents the firmness of Christ....No woman that has the Spirit of Jesus wants to usurp authority over the man. The more God uses you in the Spirit, the more humble and tender you are and [t]he more filled with the blessed Holy Spirit.

It is contrary to the Scriptures that woman should not have her part in the salvation work to which God has called her. We have no right to lay a straw in her way....It is the same Holy Spirit in the woman as in the man [13].

This excerpt demonstrates that a statement affirming women in ministry does not necessarily mean that there are no limitations on this expression of ministry. The ideas presented in "Who May Prophesy?" strongly suggest that while women may have the anointing oil and operate in prophetic functions (i.e., preaching), their realm of authority was limited from the beginning because they were subject to the authority of men. As the Pentecostal fires spread across the United States, this same type of restricted authority was maintained among the various Pentecostal denominations that sprung up.

\subsection{The Church of God and the Church of God in Christ}

Barfoot and Sheppard maintain that a regimentation and routinization of Pentecostalism, accompanied by a centralization of ecclesiastical authority, began to occur during the 1920s. The 
result, they claim, was that women began to face new hindrances and their earlier equality receded. But, once again, not only was a distinction between the prophetic and priestly functions already being made within Pentecostalism before the 1920s, especially for the Church of God and Church of God in Christ - two of the oldest and largest Pentecostal denominations - their ecclesial formation was also already well on its way prior to the 1920s. Barfoot and Sheppard's assumption that the institutionalization of the Assemblies of God was characteristic of other Pentecostal denominations is mistaken.

The formal beginning of the Church of God dates to 1886 when a small group of people founded the Christian Union. There was little growth over the course of the next ten years until a revival in 1896 at the Shearer Schoolhouse near Camp Creek, North Carolina, caused the members of the Christian Union to join forces with the North Carolina group. During this revival persons experienced glossolalia, though the Pentecostal doctrine of this manifestation did not come until later. In 1902, the Christian Union finally adopted a form of government and changed its name to The Holiness Church at Camp Creek. By 1905 there were four congregations spread across three states-Tennessee, North Carolina, and Georgia - and in 1906 they met together in Cherokee County for their first General Assembly. By 1907 the center of the church's activities had shifted to Cleveland, Tennessee, which became the headquarters, and the denomination changed its name to Church of God. In 1908 glossolalia received a renewed prominence when A.J. Tomlinson-the first General Overseer of the denomination-received Spirit baptism himself at the hands of G.B. Cashwell who had just returned from the Azusa Street revival. From this point on the Church of God was clearly Pentecostal [14].

The demarcation between ministering authority and ruling authority within the Church of God is evident as early as 1910 when A.J. Tomlinson stated that Paul's instruction for women to keep silent in the church meant that women were to keep silent in regard to church government [15]. However, while the women were to refrain from participating in priestly functions, they were more than welcome to participate in the prophetic functions of the church. A few years later Tomlinson wrote, "Let the good sisters feel at perfect liberty to preach the gospel, pray for the sick or well, testify, exhort, etc., but humbly hold themselves aloof from taking charge of the governmental affairs" [16]. Another prominent denominational leader, M.S. Lemons, articulated similar sentiments when in a General Assembly he noted that "The law of God forbids the women to speak, but in the meeting house she may preach, pray, and do all she can to lead souls to Christ. Not all gatherings are the church. But when they have met with the elders and business is being transacted the women must be quiet, and under no circumstance hold any important office" [17].

Like the Church of God, the formal beginning of the Church of God in Christ - a primarily African American Pentecostal denomination - also predates the twentieth century. In 1897 Charles Price Jones and Charles Harrison Mason held a Holiness revival in Lexington, Mississippi, which became the organizational meeting for the Church of God in Christ. During that same year the new church was incorporated as a chartered denomination and its headquarters was moved to Memphis, Tennessee. Although the Church of God in Christ had Holiness origins, in 1907 it became a Pentecostal denomination when Mason and two other ministers visited the Azusa Street revival. During Mason's time at Azusa he received the Pentecostal experience of Spirit baptism accompanied by glossolalia. However, when he returned to Memphis he found that not everyone was as enthusiastic about his Pentecostal experience, especially Jones. At the denomination's General Assembly that year in 
Jackson, Mississippi, it was decided that Mason and all those who promulgated the theology of glossolalia would be disfellowshipped. Mason, therefore, left the Assembly and took with him approximately half of the ministers and members. Whereas Mason was expelled in August of 1907, by September he had called for his own conference in Memphis to reestablish the Church of God in Christ as a Pentecostal denomination. During this meeting the old name was retained, a Pentecostal paragraph was added to the articles of faith, and Mason was elected as the General Overseer of the denomination $[18,19]$.

Similar to the history of the Church of God, the delineation between ministering authority and ruling authority in the Church of God in Christ emerged prior to the 1920s. This was enforced by differentiating linguistically between women's public voice within the church and men's. That is, women were allowed to teach, but not preach. There is evidence of this distinction operating among the denomination as early as 1911. During this year Mason brought Elizabeth "Lizzie" Robinson to attend a meeting with him at South Fort Pickering, Arkansas. While Mason convened with the men about doctrinal issues, Robinson addressed the women. During this meeting with the women, Robinson asked how many preachers there were. She recounts that thirty-two women stood up and identified themselves as such. Robinson then proceeded to lecture them about the error of their ways, as she claimed that women are not called to preach, but to teach. And when she questioned these ladies about who had told them to preach and one woman responded that God had spoken to her out of the air and told her to preach, Robinson retorted that it must have been the devil who spoke to her since he is the prince of the air and she could not be a preacher! Robinson refused to call women "preachers"including herself - making a distinction between the act of teaching (i.e., the educational function of biblical training and domesticity) and of preaching (i.e., proclamation of the Word). Her rationale for this was that at the end of Matthew, Jesus told the women to go and tell the male disciples to meet him in Galilee and it was the male disciples that Jesus then told to go into the entire world and preach the gospel. Therefore, women were not granted the assignment of preaching. Moreover, 1 Timothy 2:11-12 confirmed that women were to learn from men and stay silent in the church, but Titus 2:3-5 permitted women to teach other women. Consequently, Robinson thought women should remain silent in the church and let the men preach, but women could instruct others in the faith [20].

Robinson's perspective on this issue is significant because later in that same year at the Annual Convocation of the Church of God in Christ, Mason appointed her to be Overseer of the women's work within the denomination, which eventually became the Women's Department. As a result, Robinson's position on women in ministry became more than just a personal opinion. Her views assisted in establishing a distinction between teaching and preaching that persists within the Church of God in Christ until today. While it is highly unlikely that this distinction is due solely to Robinsonnamely because this attitude reflects the position Baptists upheld, which is the denomination that Mason himself came from - the fact that she was not challenging it and expected women to maintain it surely helped to perpetuate this understanding within the denomination [20,21].

\subsection{The Assemblies of God}

Even within the Pentecostal denomination Barfoot and Sheppard cite- the Assemblies of Godwomen's restricted authority was established from the beginning as the rights and offices of women 
were clearly delineated at the very first General Council. On the one hand it was recognized that God was using women in a powerful way to spread the good news of the gospel. Consequently, the Assemblies of God asserted that with regard to salvation women and men were equal (Gal 3:28), women were called to prophesy and preach (Acts 2:17; 1 Cor 14:3), and women were to be helpers in the gospel (Rom 16:3). On the other hand, women were also to be in subjection to men and not usurp authority over them (1 Tim 2:11-15). Therefore, based upon these principles women were permitted to be ordained as evangelists and missionaries because it was their "God-given" right, but not as elders. Once again, there was no problem with women functioning with a ministering authority, only with a ruling authority [22].

Several months after the first General Council, E.N. Bell expounded on why women could not be elders in the denominational publication The Christian Evangel, saying,

There is no instance of any woman being put in a place of authority to rule, govern or teach in the authoritative sense, that is, by the authority of their office, anywhere in the New Testament. When one speaks as a prophet, he speaks with the authority of God, but when one speaks as an apostle, he speaks with the authority of an apostle. He not only gives God's message, but he also has authority to enforce it. Likewise, the elders should speak in all love and gentleness, and yet with the authority given them in the Word of God as an elder. No woman has been known to have been appointed by the Lord as an elder or an apostle, or to any position where ruling with authority is inferred. It is not that God desires to withhold from them anything that would be a blessing to them, but rather to take these heavy responsibilities off their shoulders. While there can always be found exceptions to any human rule, it is still true that men are better adapted through their natural inheritances from the Lord than are women to rule and govern assemblies [23].

This excerpt explicitly describes the differentiation between men and women in terms of authority. The pivotal point of demarcation is what type of authority each sex is allowed to possess. A distinction is made between the type of authority that a prophet wields (i.e., a position that women are allowed to operate in), and the authority which an apostle or elder wields (i.e., positions that women are not allowed to operate in). The prophet's authority is solely a ministering authority, whereas the apostle's or elder's is a ruling authority.

Moreover, while Barfoot and Sheppard claim that in 1931 ordained women lost the rights to bury the dead, administer the ordinances of the church, and perform the right of marriage - all priestly functions - the evidence seems to suggest that women were never expected to engage in such activities except in extraordinary circumstances (i.e., a man was not available to perform them). In the fall of 1914 the Executive Presbytery stated that female missionaries in foreign countries could perform the functions listed above only if an ordained man was not available to execute them [24]. In addition, these functions were not listed on women's ordination papers until 1922. Even at this point the only reason the denomination began to list them was because their female ministers were having problems obtaining clergy rates on the railroads. The United States Clergy Bureau was questioning their full ordination. Consequently, the denomination issued new credentials to all of the ordained women in the Assemblies of God, stating that the women were authorized to administer the ordinances and perform marriages when necessary. A letter was sent to all of the ordained females explaining the situation. It said, 
While not encouraging women to be pastors, to marry people and to administer the ordinances of Baptism and the Lord's Supper, it has nevertheless been understood all along that they could do these things when some circumstances made it necessary for them to do so....

So note in your credentials the limiting phrase, "when such acts are necessary."

It is not intended to encourage the women to do these things in the future any more than in the past. They will be expected to do such things only when ordained men are not present to do them or when some such real emergency makes it necessary for them to do so....

Remember the new credentials do not change the customs among us, that you are to do such things only "when really necessary". We are only putting the unwritten custom into black and white so there will be no misunderstanding....

Be careful not to boast over having this authority or do anything to stir up opposition in places where they are opposed to women doing such things. If through lack of wisdom you should let trouble arise this might compel the Executive Presbytery to recall the new forms [25].

The "freedoms" Barfoot and Sheppard claim women lost in the Assemblies of God do not appear to have ever fully existed.

\subsection{Aimee Semple McPherson}

Although Barfoot and Sheppard lift up Aimee Semple McPherson as an exemplary "prophetic" figure within Pentecostalism, even McPherson appears to have acquiesced to the bifurcation between ministering authority and ruling authority. Born in 1890 on a small farm in Ontario, McPherson was first exposed to Pentecostalism in 1907. She became a quick convert and immediately felt a call to ministry. Her pursuit of the ministry took her across the United States and even overseas, but in the 1920s she finally settled in the Los Angeles area to start a church. McPherson built an auditorium with a seating capacity of over five thousand people and from this massive congregation emerged the denomination known as the International Church of the Foursquare Gospel that still exists today [26].

It is possible that Barfoot and Sheppard are right that McPherson's departure from the Assemblies of God was an effect of the various decisions the denomination was making, but the evidence is not altogether convincing. In 1919 McPherson received ordination as an evangelist from the Assemblies of God, but her affiliation with the denomination appears largely to be a result of Robert Craig. Craig was the dominant figure in the local Pentecostal circles of Northern California where McPherson was evangelizing at the time, and it is probable that his desire to enlist her talents for the new Pentecostal denomination - rather than McPherson's interest in attaching herself to this group-resulted in her ordination through the Assemblies of God. The formal relationship between McPherson and the Assemblies of God was quick and ended in 1922 when she returned her credentials [26]. If McPherson were leaving the denomination because of a differentiation between operating with a ministering authority instead of a ruling authority, it would be inconsistent with the restrictions and distinctions she herself perpetuated.

For example, many of the offices and duties at Angelus Temple were assigned based on stereotypical gender roles. The reception committee was composed of women, the ushers were men, 
and Angelus Temple elders were all men since women could only serve as deaconesses. Moreover, McPherson did not work very well with female associates on the platform, with the exception of her mother and daughter. Other than the female L. I. F. E. students who preached on Friday nights, women preachers only took the pulpit when McPherson was absent. When she was there, it was men alone who had this privilege [26].

In a baccalaureate sermon entitled "The Servants and the Handmaidens," McPherson made explicit her understanding of separate spheres of ministry for women and men. This sermon was given by McPherson to the students who were graduating from her Bible school and was on the subject of God's calling of servants and handmaidens. She believed that God was calling both sons and daughters and that this was in accord with the Bible because it says that sons and daughters shall prophesy (Acts 2:18). However, McPherson believed that God called women and men to different responsibilities. She related the church to a family and suggested that just like fathers and mothers have their own respective place within a natural family, so too do men and women in the church. God has a separate work for each sex to participate in [27].

This type of reasoning also emerged in a debate she participated in with a Baptist pastor named Ben Bogard. Although the primary topic of the debate was whether the supernatural gifts ended with the Apostolic Age, Bogard directed several other questions to her including the following: "Since the elder or bishop must be the husband of one wife how in the world can you qualify as an elder or bishop since you certainly can not be a husband at all. [sic] See I. Tim. 4:2...” [28]. McPherson responded to this by saying that she was not a bishop and had never claimed to be one. Rather, she claimed to be merely a handmaiden of the Lord. Moreover, in response to another question from Bogard, McPherson felt the need to point out that the Board for the International Church of the Foursquare Gospel was comprised solely of men, while she was only the pastor [28]. Therefore, despite McPherson's perceived leadership position within her church, she still assumed that women were limited to some degree with respect to ruling authority because of their sex.

\subsection{Current Status}

After the 1920s, the way the bifurcation between ministering authority and ruling authority continued over the years varies with each denomination. In the Church of God women have gradually come to acquire access to certain priestly functions, but not all. There was some measurable progress in the 1990s when women were finally permitted to receive exhorter and licensed minister credentials, and when all women - clerical and lay-received voting rights at the General Assembly. With respect to the first issue, until 1990 there were three levels of credentials for men (ordained minister, licensed minister, and exhorter), but women were only allowed to operate as "female ministers," which had been equivalent to the men's exhorter status but separate from it. However, in 1990 Church of God women were finally allowed access to the ranks of licensed minister and exhorter with the same requirements, duties, responsibilities, and ministry opportunities as male exhorters and licensed ministers. They were now able to preach, evangelize, pastor, baptize, receive believers into the church, administer the ordinances, solemnize rites of marriage, establish churches, and sit in the General Council of the ordained ministers (the denomination's clerical judicial body) while abstaining from voting [29]. With respect to the second issue, women were not allowed to speak or vote at the General 
Assembly (the denomination's lay judicial body) until 1992 when this was reversed [30]. Yet, despite the progress, female ministers were still operating with restricted freedoms because they were not ordained. Consequently, they were excluded from the governing responsibilities and offices of the denomination.

It was not until 2000 when Church of God women finally were granted the right to be ordained, albeit in a circuitous way. Up until this point there was a three-tiered system of ordained minister, licensed minister, and exhorter. It was decided that the ministerial designations needed to be changed so that those who had formerly functioned as "licensed" ministers would now be recognized as "ordained" ministers. Therefore, the three-tiered system was amended to that of ordained bishop, ordained minister, and exhorter. Despite the alteration in titles, the duties and responsibilities of the particular levels remained the same [31]. Because essentially there was no change in female clergy's ranking and they were still excluded from the highest ministerial level, they were still prohibited from holding most ecclesial leadership positions in the denomination because only an ordained bishop could be elected or appointed to them. This signifies that even now women within the Church of God are limited primarily to a ministering authority and the prophetic functions that this entails, and are barred from many areas of ruling authority and the priestly functions this entails.

In the Church of God in Christ, women have been operating in a different ministerial track from the men. That is, when Mason appointed Robinson to the position of Overseer of the women's work in 1911 a separate sphere of ministry for women in the Church of God in Christ emerged. On the positive side, this move created a somewhat autonomous space within the denomination for the women to operate. Although the women were not granted ordination, they have utilized the sphere of ministry that they had been given and carved out a niche of spiritual and temporal power for themselves despite the patriarchy that has tried to circumscribe them. They have created a space in which they can exert their own governing authority, along with ministering authority. The women's work has grown to establish its own auxiliaries and missions, to appoint and sanction its own leadership, and to provide its own financial base. Essentially women can engage in much of the traditional work of the ministrymissions, teaching, evangelism-but from a different locus and under the direction of women. Currently, the Church of God in Christ's Women's Department is the largest such auxiliary of any African American denomination and it has multiple levels of organization in local churches, jurisdictional settings, and national settings [20,32].

On the negative side, however, this move created an alternative path for women to be involved in an official capacity in the church, wherein they have been mostly limited to working with women and children. Women's calls to ministry have not been validated with ordination and they have not received formal recognition as pastors. Without either of these, women's ministerial functions and access to governing authority within the denomination are limited because they cannot proceed along the same track as the men who begin at the level of licensed minister (local preacher), and then potentially moves upward to ordained minister (elder), pastor, superintendent, jurisdictional bishop, and the General Board of bishops from which the presiding bishop is selected. In addition, women are also limited in their participation in the denomination's General Assembly. Whereas every ordained minister (elder) is eligible for participation in the General Assembly, the number of women involved is restricted [32]. Consequently, the Women's Department ultimately constitutes a separate and unequal sphere of ministry for women in the Church of God in Christ. 
In the Assemblies of God, women have not had to overcome the formal barriers of ordination or voting privileges, but the denomination still differentiated between the religious authority of a woman from that of a man until the 1970s. Sometime between 1975 and 1977 the denomination's resolution on female ministers was reworded so that it no longer asserted that there was a difference between the ministry of men and women [33]. Then, in 1977 a motion prevailed that called for the reaffirmation of the Assemblies of God's position on women's ordination, and in 1990 the denomination published a position paper entitled "The Role of Women in Ministry as Described in Holy Scripture." The paper acknowledged the historical precedent of women in the ministry, examined the multiple examples of women in the Bible who fulfilled some type of ministerial role, addressed the problematic texts that seem to restrict women, and definitively established that the ministry of women should not be restricted [33,34]. This was followed by a resolution in 1991 that explicitly stated that God's call to the ministry was without discretion regarding gender, race, disability, or national origin [35]. Finally, in 2007 it was decided that the composition of the Executive Presbytery - an elected body of twenty members that serves as the board of directors for the denomination-should be altered so that at least one of the nonresident executive presbyters is an ordained female credential holder. This resolution was implemented in 2009 when Beth Grant became the first woman to be elected to the Executive Presbytery, effectively the first woman to be elected to a senior leadership position in the denomination since its inception [36,37]. Although this move was significant, it should be noted that in 1995 and 1997 action was taken to add representation on the Executive Presbytery from Hispanic foreign language districts and other ethnic fellowships [38,39]. It took another ten years to realize that gender issues were as important as race and that sexism is no less a threat than racism.

In the International Church of the Foursquare Gospel women have made the most progress towards affirming the equality of women's and men's religious authority and embodying this stance within their denominational structure. In 1975 the denomination's official statement on "Women in Public Ministry" affirmed that the Bible demonstrates that God employs women and men equally. Therefore, the denomination saw "nothing that should restrict God-ordained and Spirit-filled ministry of women in any capacity or office of the Church" [40]. In 1988 a declaration was unanimously passed by the denomination's Board of Directors that reaffirmed the International Church of the Foursquare Gospel's position on the issue. Furthermore, a decade later, the denomination's leaders felt the need to respond to a consistent stream of inquiries regarding the International Church of the Foursquare Gospel's attitude toward women in ministry. A position statement was constructed that addressed the biblical view on women in ministry, as well as the ministry of women in the denomination. It stated that the "International Church of the Foursquare Gospel affirms the place of women in ordained ministry and leadership. This belief affords women positions in all capacities in the local church, on the mission field and at all levels of government in the Foursquare corporate structure" [40]. An important move towards making this ideal a reality occurred when Tammy Dunahoo was appointed to the denomination's second-highest position, that of General Supervisor, in 2010. According to denominational leaders, this appointment is the most significant female executive appointment since 1950 [41]. 


\section{Conclusions}

The examples presented offer just a glimpse of American women's religious history. But even a glimpse can be revealing. One can see that women's access to full and equal religious authority has been a struggle. Within this struggle women have not always been the protagonists on the issue. As demonstrated with Robinson's and McPherson's positions on Pentecostal women's religious authority, women can be strikingly ambivalent to women's plight or even adamantly opposed. This is the case because the issue of women's religious authority is not a dispute between men and women per se, but between those who support a hierarchical ideology and those who support an egalitarian ideology. The former subscribes to a dualistic anthropology, wherein the male is over the female. The latter subscribes to an egalitarian anthropology, wherein the male and female are positioned next to one another as equals. Men and women can subscribe to either position regardless of their sex.

Moreover, the issue of American women's religious authority is one that is influenced by both cultural expectations and religious beliefs. If it were solely the former, Pentecostal women would neither have experienced the freedom they did early on, nor would they still be facing some of the hurdles they do. This also helps to explain why it was not axiomatic for persons like Robinson and McPherson to support women's full and equal religious authority. Their access to power was ultimately restricted by cultural ideas that they themselves adopted.

When recounting the historical narrative of Pentecostal women in ministry, the categories of prophet and priest are helpful in distinguishing between a ministering authority and a governing authority, but they must be seen as existing simultaneously and not successively. Calling, charisma, and eschatological expectancy have always played a part in legitimating Pentecostal women's ministering authority. However, historically it has not been enough to give them access to governing authority because that generally was the sole prerogative of men. As the movement has grown over the last 100 years, women's access to governing authority has been slow in coming, especially within certain Pentecostal denominations [42-44]. Nonetheless, there has been measureable improvement and thus there is optimism that one day all Pentecostal women will have full access to both the prophetic and priestly functions within their churches [45]. As the Assemblies of God and the International Church of the Foursquare Gospel have already demonstrated, allowing women to operate with ministering authority and governing authority is not the demise of the tradition, but its future hope.

\section{References}

1. Bell, E.N. Women Welcome. Christ. Evang. 13 February 1915, 2.

2. Barfoot, C.H.; Sheppard, G.T. Prophetic vs. Priestly Religion: The Changing Role of Women Clergy in Classical Pentecostal Churches. Rev. Relig. Res. 1980, 22, 2-17.

3. Dirksen, C. Let Your Women Keep Silence. In The Promise and the Power: Essays on the Motivations, Developments, and Prospects of the Ministries of the Church of God; Bowdle, D.N., Ed.; Pathway Press: Cleveland, TN, USA, 1980; pp. 165-196.

4. Poloma, M. The Assemblies of God at the Crossroads: Charisma and Institutional Dilemmas; The University of Tennessee Press: Knoxville, TN, USA, 1989; pp. 101-121. 
5. Crews, M. The Church of God: A Social History; The University of Tennessee Press: Knoxville, TN, USA, 1990; pp. 92-107.

6. Sanders, C.J. History of Women in the Pentecostal Movement. Cyberj. Pent.-Char. Res. 1997, 2, Available online: http://www.pctii.org/cyberj/cyberj2/sanders.html (accessed on 28 April 2011).

7. Weber, M. The Sociology of Religion; Beacon Press: Boston, MA, USA, 1963; pp. 46, 104-105.

8. Roebuck, D. Limiting Liberty: The Church of God and Women Ministers, 1886-1996. Ph.D. Thesis, Graduate School of Vanderbilt University, Nashville, TN, USA, May 1997.

9. Espinosa, G. "Third Class Soldiers": A History of Hispanic Pentecostal Clergywoman in the Assemblies of God. In Philip's Daughters: Women in Pentecostal-Charismatic Leadership; Alexander, E., Yong, A., Eds.; Pickwick Publications: Eugene, OR, USA, 2009; pp. 95-111.

10. Johns, C.B. Spirited Vestments: Or, Why the Anointing Is Not Enough. In Philip's Daughters: Women in Pentecostal-Charismatic Leadership; Alexander, E., Yong, A., Eds.; Pickwick Publications: Eugene, OR, USA, 2009; pp. 170-179.

11. Bartleman, F. Another Wave Rolls In; Voice Publications: Northridge, CA, USA, 1962; p. 60.

12. Bartleman, F. Flapper Evangelism: Fashion's Fools Headed for Hell; privately printed, c. 1920; p. 2.

13. “Who May Prophesy?” Apos. Faith January 1908, 2.

14. Conn, C.W. Like a Mighty Army: A History of the Church of God, Definitive Edition; Pathway Press: Cleveland, TN, USA, 1996; pp. 3-34, 47-94, 98-100.

15. Tomlinson, A.J. Christ Our Law-Giver and King. Even. Light and COG Evang. 1 November 1910, 2.

16. Tomlinson, A.J. Paul's Statements Considered. COG Evang. 18 September 1915, 4.

17. Church of God. General Assembly Minutes 1906-1914: Photographic Reproductions of the First Ten General Assembly Minutes; White Wing Publishing House and Press: Cleveland, TN, USA, 1992; p. 133.

18. Clemmons, I.C. Bishop C.H. Mason and the Roots of the Church of God in Christ: Centennial Edition; Pneuma Life Publishing: Bakersfield, CA, USA, 1996; pp. 1-71.

19. Synan, V. The Holiness-Pentecostal Tradition: Charismatic Movements in the Twentieth Century, 2nd ed.; Wm. B. Eerdmans Publishing Co.: Grand Rapids, MN, USA, 1997; pp.70-71, 125-127.

20. Butler, A.D. Women in the Church of God in Christ: Making a Sanctified World; The University of North Carolina Press: Chapel Hill, NC, USA, 2007; pp. 34-43.

21. Best, F.O. Breaking the Gender Barrier: African-American Women and Leadership in Black Holiness-Pentecostal Churches 1890-Present. In Black Religious Leadership from the Slave Community to the Million Man March: Flames of Fire; Best, F.O., Ed.; Edwin Mellen Press: Lewiston, NY, USA, 1998; p. 155.

22. Assemblies of God. General Council Minutes and Reports: 1914-1999 [CD-ROM]; Flower Pentecostal Heritage Center: Springfield, IL, USA, 2001; 1914 Combined pp. 3, 7.

23. Bell, E.N. Women Elders. Christ. Evang. 15 August 1914, 2.

24. Blumhofer, E.L. The Assemblies of God: A Chapter in the Story of American Pentecostalism, Volume 1-1941; Gospel Publishing House: Springfield, IL, USA, 1989; p. 290.

25. Assemblies of God Credential Committee. Letter to Assemblies of God Ordained Women Ministers; Flower Pentecostal Heritage Center: Springfield, IL, USA, 1922. 
26. Blumhofer, E.L. Aimee Semple McPherson: Everybody's Sister; Wm. B. Eerdmans Publishing Co.: Grand Rapids, MN, USA, 1993; pp. 99-280, 360-363.

27. McPherson, A.S. The Servants and the Handmaidens: Baccalaureate Sermon. Brid. Call Foursq. 1930, 8,5 .

28. McPherson, A.S.; Bogard, B.M. Bogard-McPherson Debate: McPhersonism, Holy Rollerism, Pentecostalism, Divine Healing; Privately printed: Little Rock, AK, USA, 1934; pp. 29, 84-85.

29. Church of God. Church of God General Assembly Minutes 1906-2002 [CD-ROM]; Hal Bernard Dixon Jr. Pentecostal Research Center: Cleveland, TN, USA, 2006; 1990, pp. 79,191-92.

30. Church of God. Church of God General Assembly Minutes 1906-2002 [CD-ROM]; Hal Bernard Dixon Jr. Pentecostal Research Center: Cleveland, USA, 2006; 1992, p. 73.

31. Church of God. Church of God General Assembly Minutes 1906-2002 [CD-ROM]; Hal Bernard Dixon Jr. Pentecostal Research Center: Cleveland, USA, 2006; 2000, pp. 81-82.

32. Ware, F.L. Spiritual Egalitarianism, Ecclesial Pragmatism, and the Status of Women in Ordained Ministry. In Philip's Daughters: Women in Pentecostal-Charismatic Leadership; Alexander, E., Yong, A., Eds.; Pickwick Publications: Eugene, OR, USA, 2009; pp. 219-221.

33. Assemblies of God. General Council Minutes and Reports: 1914-1999 [CD-ROM]; Flower Pentecostal Heritage Center: Springfield, MO, USA, 2001; 1977, p. 100.

34. Assemblies of God. The Role of Women in Ministry as Described in Holy Scripture: A Position Paper of the General Council of the Assemblies of God; Gospel Publishing House: Springfield, MO, USA, 1990; pp. 1-11.

35. Assemblies of God. General Council Minutes and Reports: 1914-1999 [CD-ROM]; Flower Pentecostal Heritage Center: Springfield, MO, USA, 2001; 1991, p. 98.

36. Assemblies of God. Minutes of the $52^{\text {nd }}$ Session of the General Council of the Assemblies of God; General Council of the Assemblies of God: Springfield, MO, USA, 2007; pp. 33-35.

37. McMullen, C. Assemblies of God Pick A Woman to Help Lead. The Ledger.com [Online], 5 August 2009. Available online: http://www.theledger.com/article/20090805/news/ 908055045 (accessed on 28 April 2011).

38. Assemblies of God. General Council Minutes and Reports: 1914-1999 [CD-ROM]; Flower Pentecostal Heritage Center: Springfield, MO, USA, 2001; 1995, pp. 14-17.

39. Assemblies of God. General Council Minutes and Reports: 1914-1999 [CD-ROM]; Flower Pentecostal Heritage Center: Springfield, MO, USA, 2001; 1997, pp. 23-28.

40. International Church of the Foursquare Gospel. Women in Ordained Leadership Ministry; International Church of the Foursquare Gospel: Los Angeles, CA, USA, 1998.

41. Gaines, A.S. Foursquare Appointment One of Most Significant in 50 Years. Charisma News Online [Online], 8 July 2010. Available online: http://www.charismamag.com/index.php/news/ 28877-foursquare-appointment-one-of-most-significant-in-50-years (accessed on 28 April 2011).

42. Gill, D.M. The Contemporary State of Women in Ministry in the Assemblies of God. Pneuma 1995, 17, 33-36.

43. Roebuck, D. Perfect Liberty to Preach the Gospel: Women Ministers in the Church of God. Pneuma 1995, 17, 25-32.

44. Kay, W.K. A Woman's Place is on Her Knees: The Pastor's View of the Role of Women in the Assemblies of God. J. Europ. Pent. Theo. Assoc. 1998, 18, 64-75. 
45. Stephenson, L.P. Dismantling the Dualisms for American Pentecostal Women in Ministry: A Feminist-Pneumatological Approach; Brill: Leiden, The Netherlands, 2011.

(C) 2011 by the authors; licensee MDPI, Basel, Switzerland. This article is an open access article distributed under the terms and conditions of the Creative Commons Attribution license (http://creativecommons.org/licenses/by/3.0/). 